\title{
Correction: Addison's disease presenting with idiopathic intracranial hypertension in 24-year-old woman: a case report
}

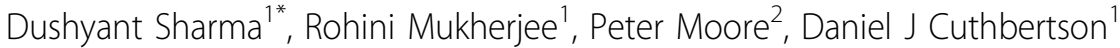

\section{Correction}

Following the publication of our article [1] an error in the case presentation section was noted. In the description of the lumbar puncture procedure, we incorrectly stated the units of the opening pressure.

Upon lumbar puncture, performed in the lateral decubitus position, an opening pressure of $40 \mathrm{~mm}$ of water was documented.

Should read:

Upon lumbar puncture, performed in the lateral decubitus position, an opening pressure of $40 \mathrm{~cm}$ of water was documented.

\section{Author details}

'Department of Diabetes and Endocrinology, Clinical Sciences Centre, University Hospital Aintree, Liverpool L9 7AL, UK. ${ }^{2}$ Department of Neurology, Walton Centre for Neurology and Neurosurgery NHS Trust, Liverpool L9 7AL, UK.

Received: 26 October 2010 Accepted: 15 November 2010

Published: 15 November 2010

\section{Reference}

1. Sharma D, Mukherjee R, Moore P, Cuthbertson DJ: Addison's disease presenting with idiopathic intracranial hypertension in 24-year-old woman: a case report. Journal of Medical Case Reports 2010, 4:60

\section{doi:10.1186/1752-1947-4-362}

Cite this article as: Sharma et al.: Correction: Addison's disease presenting with idiopathic intracranial hypertension in 24-year-old woman: a case report. Journal of Medical Case Reports 2010 4:362.

\footnotetext{
* Correspondence: dushyantsharma@hotmail.com 1 Department of Diabetes and Endocrinology, Clinical Sciences Centre University Hospital Aintree, Liverpool L9 7AL, UK

Full list of author information is available at the end of the article
}

Submit your next manuscript to BioMed Central and take full advantage of:

- Convenient online submission

- Thorough peer review

- No space constraints or color figure charges

- Immediate publication on acceptance

- Inclusion in PubMed, CAS, Scopus and Google Scholar

- Research which is freely available for redistribution

Submit your manuscript at www.biomedcentral.com/submit 